\title{
KEBERMAKNAAN HIDUP IBU RUMAH TANGGA DENGAN HIV/AIDS DI KELOMPOK DUKUNGAN SEBAYA "SMILE PLUS" TEMANGGUNG
}

\author{
Ayu Rakhma Windarti \\ Politeknik Kesejahteraan Sosial Bandung,aayurakhma@gmail.com \\ Moch Zaenal Hakim \\ Politeknik Kesejahteraan Sosial Bandung, jejenhkm@yahoo.com \\ Uke Hani Rasalwati \\ Politeknik Kesejahteraan Sosial Bandung, hanirasalwatiuke@gmail.com
}

\begin{abstract}
This study aims to examine the meaning of life of housewifes living with HIV/AIDS in the "Smile Plus" KDS Temanggung. Aspects of the meaning of life used are: purpose of life, life satisfaction, freedom of life, attitude towards death, thoughts about suicide, and appropriateness to live. This research uses descriptive qualitative method. The data sources consist of four main informants and three supporting informants who were selected by purposive sampling. The techniques used in data collection include in-depth interviews, observation, and documentation studies. Data analysis techniques used are data collection, data reduction, data presentation, and drawing conclusions. The results of this study indicate that the purpose of life for housewifes with HIV/AIDS is to always be given health. Barriers experienced in achieving life goals are related to health, not everyone is willing to accept the situation with the status of PLWHA, and hereditary problems where non-PLWHA couples are still afraid to have children from themselves. Satisfaction in life is always being grateful for what you have and can be useful for others. Freedom of life is freedom in socializing in society. The view of death for them is that everyone will experience death so they have to do a lot of good. Thoughts about suicide occur because they feel they have no hope of life because they are infected with HIV/AIDS. The worth to live for them is because life is full of trials so that life needs to be fought for.
\end{abstract}

Keywords: housewife, people living with HIV/AIDS, the Meaning of Life

Abstrak
Penelitian ini bertujuan untuk mengkaji kebermaknaan hidup ibu rumah tangga
dengan HIV/AIDS di KDS "Smile Plus" Temanggung. Aspek kebermaknaan
hidup yaitu: tujuan hidup, kepuasan hidup, kebebasan hidup, sikap terhadap
kematian, pikiran tentang bunuh diri, dan kepantasan untuk hidup. Penelitian ini
menggunakan metode kualitatif deskriptif. Sumber data empat informan utama 
dan tiga informan pendukung berdasarkan purposive sampling. Teknik pengumpulan data meliputi wawancara mendalam, observasi, dan studi dokumentasi. Teknik analisis data yang digunakan adalah pengumpulan data, reduksi data, penyajian data, dan penarikan kesimpulan. Hasil penelitian menunjukkan bahwa tujuan hidup ibu rumah tangga dengan HIV/AIDS yaitu ingin selalu diberikan kesehatan. Hambatan yang dialami dalam mencapai tujuan hidup adalah terkait kesehatan, tidak semua orang mau menerima keadaannya yang berstatus Orang dengan HIV/AIDS (ODHA), dan permasalahan keturunan dimana pasangan yang bukan ODHA masih takut untuk memiliki keturunan dari dirinya. Kepuasan dalam hidup adalah selalu bersyukur atas apa yang dimiliki dan dapat bermanfaat bagi orang lain. Kebebasan hidup adalah kebebasan dalam bersosialisasi di masyarakat. Pandangan kematian bagi mereka adalah setiap orang akan mengalami kematian sehingga harus banyak melakukan kebaikan. Pikiran tentang bunuh diri terjadi karena mereka merasa tidak memiliki harapan hidup karena terinfeksi HIV/AIDS. Kepantasan untuk hidup bagi mereka adalah karena hidup penuh cobaan sehingga hidup perlu diperjuangkan.

\section{Kata Kunci: Ibu Rumah Tangga, kebermaknaan Hidup, orang dengan} HIV/AIDS 


\section{PENDAHULUAN}

HIV/AIDS dimulai ketika tahun 1979 di Amerika Serikat ditemukan seorang gay muda dengan Pneumocytis Carinii dan dua orang gay muda dengan Sarcoma Kapos. Selanjutnya, tahun 1981 ditemukan seorang gay muda dengan kerusakan sistem kekebalan tubuh. Epidemik HIV/AIDS pertama terjadi di Amerika Utara dan Inggris pada kelompok laki-laki homoseksual. Kasus AIDS di Indonesia pertama kali ditemukan pada tahun 1987 dari seorang wisatawan Belanda, dan hingga saat ini Kasus HIV/AIDS di Indonesia semakin meningkat setiap tahunnya (Katiandagho, D. 2012).

Menurut Direktorat Jenderal Pencegahan dan Pengendalian Penyakit (Ditjen P2P) Kementerian Kesehatan Republik Indonesia, tahun 2020 jumlah kumulatif kasus HIV sebanyak 419.551 orang, sedangkan jumlah kumulatif kasus AIDS sebanyak 129.740 orang. Mengacu pada sumber Direktorat Jenderal Pencegahan dan Pengendalian Penyakit (Ditjen P2P) Kementerian Kesehatan Republik Indonesia tahun 2020, kasus HIV dan AIDS Menurut jenis pekerjaannya, distribusi kasus AIDS terbanyak tenaga non professional (karyawan) sebesar $15,95 \%$, ibu rumah tangga sebesar 14,18\%, wiraswasta/usaha sendiri sebesar $12,67 \%$, petani/peternak/nelayan sebesar $4,87 \%$, buruh kasar sebesar 4,67\%, lain-lain sebesar 47,66\%. Provinsi dengan Lima besar kasus HIV/AIDS yaitu di Provinsi Papua, Jawa Timur, Provinsi Jawa Tengah, Provinsi DKI Jakarta, dan Provinsi Bali.

Kabupaten Temanggung termasuk wilayah yang sudah melaporkan kasus HIV/AIDS. Menurut data Dinas Kesehatan Kabupaten Temanggung (2018) dilaporkan 19 kasus HIV dan 33 kasus AIDS. Beberapa kasus HIV/AIDS di Kabupaten Temanggung dialami oleh beberapa kelompok perilaku berisiko seperti pengguna narkoba jarum suntik, pekerja seks komersial dan sebagainya. Selain itu, HIV/AIDS juga dialami oleh ibu rumah tangga yang sebagian besar tertular dari pasangannya (Susilowati,E \& Dewi K, 2019). Berdasarkan data Komisi Penanggulangan AIDS (KPA) Kabupaten Temanggung tahun 2019, jumlah kasus HIV/AIDS mencapai 480 kasus dengan rincian 249 kasus HIV dan 231 kasus AIDS, dengan 30 diantaranya adalah balita yang disebabkan dari faktor prenatal.

Orang dengan HIV/AIDS (ODHA) memiliki banyak sekali permasalahan. Bukan hanya masalah fisik dan kesehatan saja, namun lebih jauh dari itu ODHA banyak yang mengalami permasalahan psikososial. Menurut Hawari (Kusumawijaya, 2012), penderita AIDS akan mengalami krisis kejiwaan pada dirinya, pada keluarganya, pada orang yang dicintainya dan pada masyarakat. Krisis kejiwaan tersebut adalah dalam bentuk kepanikan, ketakutan, kecemasan, serba ketidakpastian, keputusasaan, dan stigma.

Perlakuan terhadap penderita AIDS seringkali bersifat diskriminatif dan risiko bunuh diri pada penderita AIDS cukup tinggi akibat depresi mental yang dialaminya. Kondisi ini yang menyebabkan ODHA menjadi kehilangan makna hidupnya, merasa dirinya rendah, tidak berdaya dan merasa hampa. Mereka sulit menerima keadaan dirinya hingga timbul pikiran-pikiran negatif yang ada di dalam dirinya. AyyashAbdo (2002) menuturkan bahwa percobaan bunuh diri merupakan perilaku yang muncul akibat keputusasaan dalam menjalani kehidupan dan akibat dari anggapan bahwa setiap tujuan hidup yang diharapkan tidak akan pernah bisa tercapai. 
Frankl (2000) menyatakan bahwa kebermaknaan hidup adalah keadaan yang menunjukkan sejauh mana seseorang telah mengalami dan menghayati kepentingan keberadaan hidupnya menurut sudut pandang dirinya sendiri. Kebermaknaan hidup dapat ditemukan dan dilihat dengan berbagai aspek seperti tujuan hidup, kepuasan hidup, kebebasan, sikap terhadap kematian, pikiran tentang bunuh diri, serta kepantasan untuk hidup. Sementara itu Menurut Argyle (Astuti \& Budiyani, 2014) faktor-faktor yang dapat mempengaruhi kebermaknaan hidup seseorang, di antaranya yaitu: faktor internal meliputi pemahaman diri, bertindak positif, pengakraban lingkungan, pendalaman tri nilai, dan ibadah. Sementara untuk faktor eksternal meliputi : material, pekerjaan, dan dukungan sosial

Lebih lanjut Bastaman (2007) berpendapat bahwa ketika seorang individu memiliki penghayatan bahwa hidupnya memiliki makna, maka individu tersebut sedang dalam proses menuju ke arah kepuasan hidup dan kebahagiaan hidup dimana.

Berdasarkan fakta dan data yang ada, permasalahan dan fenomena mengenai kebermaknaan hidup ODHA ini terjadi di Kelompok Dukungan Sebaya Smile Plus Temanggung. Lembaga ini memiliki fokus masalah pada peningkatan mutu kualitas hidup orang yang terinfeksi HIV/AIDS serta mengupayakan kesejahteraan ODHA di wilayah Kabupaten Temanggung yang secara resmi menjadi anggota dalam Kelompok Dukungan Sebaya Smile Plus Temanggung. Berdasarkan informasi dari pengurus Smile Plus, hampir 50\% dari 71 (tujuh puluh satu) ODHA yang ada di KDS Smile Plus Temanggung mengalami depresi, tidak percaya, sedih, kecewa, sehingga cukup lama untuk menerima keadaannya sebagai ODHA.
Ibu Rumah Tangga dengan HIV/AIDS adalah salah satu kelompok yang mengalami permasalahan tersebut. Para Ibu Rumah Tangga mengalami masalah antara dirinya, pasangannya, anaknya, keluarga besarnya, maupun tetangga sekitar. Meskipun mereka menerima keadaan dirinya sebagai ODHA, akan tetapi mereka sulit memaknai hidup karena takut akan stigma dan diskriminasi dari orang sekitarnya.

Melihat dari fenomena berdasarkan fakta dan data diatas, maka penelitian tertarik untuk melakukan penelitian kebermaknaan hidup dikalangan Ibu Ruamh Tangga yang positif HIV. Penelitian ini sangat penting untuk memberikan rekomendasi terkait upaya yang dapat dilakukan agar ODHA khususnya Ibu Rumah Tangga dapat memaknai hidupnya dan dapat hidup dengan tenang tanpa merasa depresi ataupun tertekan dengan kondisi yang dialaminya sekarang.

Penelitian ini akan melihat aspek-aspek kebermaknaan hidup ODHA dikalangan Ibu rumah tangga berdasarkan 6 (enam) aspek yaitu: 1. Tujuan hidup, yaitu sesuatu yang menjadi pilihan, memberi nilai khusus serta dijadikan tujuan dalam hidupnya.

2. Kepuasan hidup, yaitu penilaian seseorang terhadap hidupnya, sejauh mana ia bisa menikmati dan merasakan kepuasan dalam hidup dan aktivitas-aktivitas yang dijalaninya.

3. Kebebasan, yaitu perasaan mampu mengendalikan kebebasan hidupnya secara bertanggungjawab.

4. Sikap terhadap kematian, yaitu bagaimana seseorang berpandangan dan kesiapannya dalam menghadapi kematian. Orang yang memiliki makna hidup akan membekali diri dengan berbuat kebaikan, sehingga dalam memandang kematian akan merasa siap untuk menghadapinya.

5. Pikiran tentang bunuh diri, yaitu bagaimana pemikiran seseorang tentang masalah bunuh 
diri. Bagi orang yang mempunyai makna hidup akan berusaha menghindari keinginan untuk melakukan bunuh diri atau bahkan tidak pernah memikirkannya.

6. Kepantasan hidup, adalah evaluasi seseorang tentang hidupnya apakah ia merasa bahwa sesuatu yang dialaminya merupakan sesuatu yang wajar sekaligus menjadi tolok ukur baginya tentang mengapa hidup itu layak untuk diperjuangkan.

Penelitian terhadap keenam aspek kebermaknaan hidup ini juga akan megacu kepada beberapa konsep penting dari kebermaknaan hidup itu sendiri yaitu terkait dengan sumber kebermaknaan hidup dan karakterisktik kebermaknaan hidup.

Sumber kebermaknaan hidup menurut Frankl dalam Bastaman (2007) mencakup beberapa unsur yaitu:

1. Creative Values (Nilai-nilai Kreatif)

Nilai-nilai kreatif mencakup kegiatan bekerja, berkarya serta melaksanakan tugas dan kewajiban sebaik-baiknya dengan penuh tanggung jawab. Menekuni suatu pekerjaan dan meningkatkan keterlibatan pribadi terhadap tugas serta berusaha untuk mengerjakannya dengan sebaik-baiknya merupakan salah satu contoh kegiatan berkarya. Melalui berkarya dan kerja kita dapat menemukan arti hidup dan menghayati kehidupan secara bermakna.

2. Experiential Values (Nilai Penghayatan)

Keyakinan dan penghayatan akan nilainilai kebenaran, kebajikan, keindahan, keimanan, dan keagamaan serta cinta kasih. Menghayati dan meyakini suatu nilai dapat menjadikan seseorang berarti hidupnya. Beberapa orang merasa menemukan arti hidup dari agama yang diyakininya, menekuni cabang seni tertentu, maupun dengan mencintai dan dicintai seseorang akan merasakan hidupnya penuh dengan pengalaman hidup yang membahagiakan.

3. Attitudinal Values (Nilai-nilai Bersikap)

Menerima dengan penuh ketabahan, kesabaran, dan keberanian dalam segala bentuk penderitaan. Dalam hal ini yang diubah bukan keadaannya melainkan sikap (attitude) yang diambil dalam menghadapi keadaan itu. Ini berarti apabila menghadapi keadaan yang tak mungkin diubah atau dihindari, sikap yang tepatlah yang masih dapat dikembangkan. Penderitaan memang dapat memberikan makna hidup dan berguna apabila kita dapat mengubah sikap terhadap penderitaan itu menjadi lebih baik lagi. Ini berarti bahwa dalam keadaan bagaimanapun arti hidup masih dapat ditemukan, asalkan dapat mengambil sikap yang tepat dalam menghadapinya.

Sementara itu karakteristik kebermaknaan hidup lebih lanjut dikemukakan oleh Bastaman (2007) sebagai berikut:

1. Bersifat Unik, Pribadi, dan Temporer Apa yang dianggap berarti oleh seseorang belum tentu berarti pula bagi pula bagi orang lain. Dalam hal ini makna hidup seseorang dan apa yang bermakna bagi dirinya biasanya sifatnya khusus, berbeda dan tak sama dengan makna hidup orang lain, serta mungkin pula dari waktu ke waktu berubah

2. Bersifat Spesifik dan Nyata

Makna hidup benar-benar dapat ditemukan dalam pengalaman dan kehidupan seharihari. Mengingat keunikan dan kekhususannya itu, makna hidup tidak dapat diberikan oleh siapapun melainkan harus dicari, dijajagi, dan ditemukan sendiri.

3. Bersifat Memberi Pedoman dan Arah

Dalam hal ini, begitu makna hidup ditemukan dan tujuan hidup ditentukan, kita 
seakan-akan terpanggil untuk melaksanakan dan memenuhinya, serta kegiatan kita menjadi lebih terarah kepada pemenuhan itu.

Dalam kaitannya dengan situasi ketidakberhasilan menemukan dan memenuhi makna hidup, seringkali seseorang akan mengalami penghayatan hidup tanpa makna (meaningless), hampa, gersang, merasa tak memiliki tujuan hidup, merasanya hidupnya tak berarti, bosan, dan apatis. Dalam perilaku dan kehendak yang berlebihan biasanya tersirat penghayatan-penghayatan hidup tanpa makna.

Ciri-ciri kehilangan makna hidup menurut Crumbaugh dan Maholick (Bastaman, 2007) adalah perasaan hampa, gelisah, merasa tidak memiliki tujuan hidup, merasa hidup tidak berarti, serba salah, kehilangan minat, dan kehilangan inisiatif sehingga individu tidak ada gairah lagi untuk menjalani kehidupan di masyarakat.

Penghayatan hidup bermakna merupakan gerbang kearah kepuasan dan kebahagiaan hidup. Artinya, hanya dengan memenuhi maknamakna potensial yang ditawarkan oleh kehidupanlah penghayatan hidup bermakna tercapai dengan kepuasan dan kebahagiaan sebagi ganjarannya. Mereka yang menghayati hidup bermakna benar-benar tahu untuk apa mereka hidup dan bagaimana mereka menjalani hidup. Ciri-ciri hidup bermakna menurut Bastaman (2007) adalah sebagai berikut :

1. Menjalani kehidupan sehari-hari dengan penuh semangat dan penuh gairah serta jauh dari perasaan hampa

2. Tujuan hidup yang jelas, baik jangka pendek dan jangka panjang sehingga individu akan menjadi lebih terarah dan merasakan kemajuan-kemajuan yang telah dicapai

3. Kegiatan-kegiatan yang dilakukan terarah

4. Mampu merasakan kemajuan-kemajuan yang telah tercapai
5. Tugas-tugas dan pekerjaan sehari-hari merupakan sumber kepuasan dan kesenangan tersendiri sehingga mampu mengerjakan dengan semangat dan bertanggung jawab

6. Hari demi hari mampu menemukan beraneka ragam pengalaman baru dan hal-hal menarik yang dapat menambah pengalaman hidup

7. Mampu menyesuaikan diri dengan lingkungan, menyadari batasan-batasan lingkungan

8. Menyadari bahwa makna hidup dapat ditemukan dalam kehidupan itu sendiri, walaupun dalam keadaan buruk yang dialami

9. Benar-benar menghargai hidup dan kehidupan

10. Mampu mencintai dan menerima cinta kasih orang lain

Menurut Bastaman (2007), ada beberapa tahap dalam proses mencapai kebermaknaan hidup yang akan dilalui oleh seseorang. Tahapan itu terdiri dari 4 (empat) tahap yaitu 1) Tahap Derita (peristiwa tragis, penghayatan tanpa makna). Dalam tahap ini, individu berada dalam keadaan yang tidak bermakna. Bisa jadi mengalami peristiwa tragis yang tidak menyenangkan; 2) Tahap Penerimaan Diri (pemahaman diri dan pengubahan sikap). Individu dapat mulai sadar dan menerima serta memahami keadaannya dari kisah tragis yang dialaminya sehingga mau tidak mau harus membuat pengubahan sikap yang lebih baik. 3) Tahap Penemuan Makna Hidup (penemuan makna dan penentuan tujuan hidup). Individu mulai menyadari akan hal-hal penting dalam kehidupannya yang kemudian ditetapkan sebagai tujuan hidupnya. Hal ini bersumber dari nilai kreatif, nilai penghayatan dan nilai sikap; dan 4) Tahap Kehidupan Bermakna (penghayatan bermakna, kebahagiaan). Timbul perubahan kondisi hidup yang lebih baik dan telah mencapai 
tujuan hidupnya dengan kebahagiaan sebagai hasilnya.

\section{METODE}

Metode yang digunakan dalam penelitian ini adalah kualitatif deskriptif. Tujuan dari penelitian ini adalah untuk mendapatkan gambaran mengenai Kebermaknaan Hidup Ibu Rumah Tangga dengan HIV/AIDS secara mendalam. Peneliti mengkaji tentang Kebermaknaan Hidup Ibu Rumah Tangga dengan HIV/AIDS di Kelompok Dukungan Sebaya Smile Plus Temanggung.

Penentuan informan yang dilakukan dalam penelitian ini adalah dengan menggunakan purposive sampling. Penentuan sumber informasi secara purposive dilandasi tujuan atau pertimbangan tertentu terlebih dahulu. Oleh karena itu, pengambilan sumber informasi (informan) didasarkan pada maksud yang telah ditetapkan sebelumnya.

Informan penelitian adalah Ibu Rumah Tangga positif ODHA dan pengurus Kelompok Dukungan Sebaya Smile Plus Temanggung. Informan Ibu Rumah Tangga positif ODHA dipilih sebanyak 4 (empat) orang dengan kriteria Ibu rumah tangga yang mengidap HIV/AIDS dan tergabung dalam Kelompok Dukungan Sebaya Smile Plus Temanggung 2, berdomisili di Temanggung, Telah mengidap HIV/AIDS lebih dari 5 tahun, berusia minimal 20 tahun dan maksimal 45 tahun, anggota aktif di Kelompok Dukungan Sebaya Smile Plus Temanggung, dan bersedia menjadi informan.

Informan lainnya adalah pengurus Kelompok Dukungan Sebaya Smile Plus Temanggung sebanyak 1 (satu) orang dengan kriteria pengurus aktif, sudah bekerja minimal 8 tahun, mengenal informan Ibu rumah tangga positif HIV, dan bersedia menjadi informan.

\section{HASIL PENELITIAN}

Penelitian kebermaknaan hidup ibu rumah tangga dengan HIV/AIDS di Kelompok Dukungan sebaya "Smile Plus" Temanggung, mencakup karakteristik informan, tujuan hidup bagi ibu rumah tangga dengan HIV/AIDS, kepuasan hidup bagi ibu rumah tangga dengan HIV/AIDS, kebebasan bagi ibu rumah tangga dengan HIV/AIDS, sikap terhadap kematian bagi ibu rumah tangga dengan HIV/AIDS, pikiran tentang bunuh diri bagi ibu rumah tangga dengan HIV/AIDS, serta kepantasan untuk hidup bagi ibu rumah tangga dengan HIV/AIDS.

\section{Karakteristik Informan}

Karakteristik informan utama adalah ibu rumah tangga yang mengidap HIV/AIDS dan tertular dari suaminya melalui hubungan seksual. Dua informan memiliki anak, namun sudah meninggal saat bayi karena terinfeksi HIV/AIDS. Satu informan mengatakan anaknya tidak terinfeksi HIV/AIDS karena sudah mengantisipasi dengan minum ARV saat hamil, melahirkan dengan sesar, dan menghindari menyusui. Reaksi pertama mereka ketika mengetahui terinfeksi HIV adalah kaget, syok, depresi, bahkan ada yang berpikir untuk bunuh diri karena merasa tidak memiliki harapan hidup.

Karakteristik informan pendukung yang ditemukan adalah merupakan ODHA dan OHIDHA. Dua informan ODHA merupakan koordinator KDS “Smile Plus" Temanggung dan suami dari informan utama yang sudah mengidap HIV/AIDS selama 15 tahun.

Tabel 1. Karakteristik Informan

\begin{tabular}{|c|c|c|}
\hline Nam: & Usia & Status \\
\hline $\mathrm{N}$ & 32 tahun & ODHA \\
\hline $\mathrm{F}$ & 40 tahun & ODHA \\
\hline $\mathrm{P}$ & 41 tahun & ODHA \\
\hline $\mathrm{L}$ & 45 tahun & ODHA \\
\hline
\end{tabular}




\begin{tabular}{|r|r|c|}
\hline M & 37 tahun & $\begin{array}{r}\text { Koordinator Smile } \\
\text { Plus/ODHA }\end{array}$ \\
\hline IE & 40 tahun & Suami F/ODHA \\
\hline W & 30 tahun & Suami N/Bukan ODH \\
\hline
\end{tabular}

\section{Tujuan Hidup}

Tujuan hidup dianggap penting bagi kehidupan seseorang sehingga orang tersebut memiliki arah untuk kedepannya.

a. Arti hidup bagi ibu rumah tangga dengan HIV/AIDS bermacam-macam seperti terus semangat menjalani hidup, saling membantu sesama, dan melakukan kegiatan-kegiatan yang positif. Informan F dan informan P mengatakan bahwa arti hidupnya saat ini adalah melakukan halhal positif seperti saling membantu khususnya dengan sesama ODHA. Informan L dan $\mathrm{N}$ mengatakan bahwa arti hidupnya yaitu terus menjalani hidup dengan status ODHA dan tetap semangat dalam mengonsumsi ARV.

b. Tujuan hidup bagi ibu rumah tangga dengan HIV/AIDS menurut seluruh informan adalah selalu diberikan kesehatan, diberikan keturunan, serta kebahagiaan dalam keluarga.

c. Alasan memilih tujuan hidup yaitu informan $\mathrm{L}$ mengatakan dengan diberi kesehatan dapat mudah melakukan kegiatan apapun dan informan $\mathrm{N}$ menuturkan bahwa setiap orang yang berumah tangga pasti ingin menjadi keluarga yang lengkap dan bahagia.

d. Orang yang paling berarti dalam hidup mereka menurut semua informan adalah keluarga terutama suami mereka.

e. Tempat menemukan arti hidup bagi ibu rumah tangga dengan HIV/AIDS adalah di keluarga dan KDS "Smile Plus" Temanggung. f. Hambatan yang dialami adalah terkait dengan masalah kesehatan, masalah keturunan, dan masalah lingkungan sekitar kurang mendukung kegiatan yang dilakukan oleh ODHA. Informan F mengatakan terkadang orang sekitarnya masih berpikir negatif tentang dirinya. Sedangkan informan L mengatakan cuaca mempengaruhi kondisi kesehatannya. Informan $\mathrm{P}$ dan $\mathrm{N}$ mengatakan hambatannya yaitu terkait keturunan. Dipertegas oleh informan $\mathrm{W}$ yang merupakan suami informan $\mathrm{N}$ dan merupakan OHIDHA (Orang Hidup Dengan HIV/AIDS) bahwa ia masih takut untuk memiliki anak dari istrinya tersebut.

g. Cara mengatasi hambatan bagi semua informan adalah dengan terus ikhtiar, tenang, ikhlas, dan sabar. Percaya kepada Allah karena semua ini sudah diatur oleh Allah.

h. Orang yang membantu mengatasi masalah dalam hidup adalah pihak keluarganya seperti suami, ibu kandung, ibu mertua, kakak kandung, kakak ipar, serta dari KDS Smile Plus Temanggung. Hal ini dututurkan oleh seluruh informan.

\section{Kepuasan Hidup}

Kepuasan hidup bagi ibu rumah tangga dapat dilihat dari kehidupannya sekarang,

melalui sudut pandang mereka, sejauh mana mereka mampu untuk menikmati dan merasakan kepuasan dalam hidup dari segala aktivitas yang telah dilakukannya.

a. Arti kepuasan hidup bagi ibu rumah tangga dengan HIV/AIDS menurut informan $\mathrm{N}$ dan $\mathrm{F}$ yaitu dapat membantu sesama, dan bagi informan $\mathrm{L}$ dan $\mathrm{P}$ adalah bermanfaat untuk orang lain serta selalu 
bersyukur atas apa yang dimiliki sekarang.

b. Hal yang membuat puas dalam hidup adalah menjadi istri yang baik, membantu dan bermanfaat bagi orang lain, sesekali melihat ke masa lalu dan bersyukur serta tetap menikmati hidup.

c. Alasan memilih kepuasan hidup yaitu dengan melihat kebawah kepada orangorang yang lebih membutuhkan dan mengambil hikmah dari kondisi sekarang sehingga menjadi lebih bersyukur dan dapat merasakan kebahagiaan.

d. Cara mencapai kepuasan hidup dengan menjaga apa yang dimiliki sekarang, berbuat kebaikan dengan sesama manusia seperti membantu menguatkan sesama ODHA, memberikan bentuk perhatian kepada sesama teman sebaya dan saling melengkapi dalam keluarga.

\section{Kebebasan Hidup}

Adanya perasaan bebas dari ibu rumah tangga dengan HIV/AIDS di KDS Smile Plus Temanggung dapat menggambarkan bagaimana kebermaknaan hidup dapat dirasakan. Kebebasan disini bukan berarti kebebasan yang sifatnya tidak terikat atau hidup bebas, namun kebebasan hidup yang dimaksud disini adalah kebebasan hidup

namun tetap sesuai dengan norma-norma yang berlaku di masyarakat.

a. Arti kebebasan hidup bagi ibu rumah tangga dengan HIV/AIDS menurut semua infoman adalah dengan bersosialisasi dan beraktivitas baik di lingkungan masyarakat atau di lingkungan KDS Smile Plus Temanggung.

b. Kebebasan hidup yang dirasakan oleh keempat informan utama lebih merasakan kebebasan ketika bercerita bersama suami dan ketika berada di KDS "Smile Plus" Temanggung. Karena, semua informan sudah terbuka kepada suami masingmaisng mengenai statusnya sebagai ODHA. Sedangkan di KDS "Smile Plus" Temanggung sendiri, mereka lebih merasa bebas karena mereka diterima dengan baik dan memiliki teman-teman yang satu komunitas dengannya.

c. Waktu merasakan kebebasan hidup bagi informan $\mathrm{N}$ dan informan $\mathrm{L}$ adalah setiap hari. Sedangkan informan $\mathrm{F}$ dan informan $\mathrm{P}$ mengatakan bahwa waktu merasakan kebebasan hidup ketika sedang bersama teman sebaya di KDS "Smile Plus" Temanggung.

d. Orang yang memberikan kekuatan dalam hidup adalah Allah SWT, keluarga, suami dan dari komunitas KDS "Smile Plus" Temanggung.

e. Perbedaan kebebasan hidup yang dirasakan sebelum dan sesudah terinfeksi HIV/AIDS bagi ibu rumah tangga di KDS "Smile Plus" Temanggung berdasarkan penuturan informan $\mathrm{P}$, informan $\mathrm{F}$, dan informan $\mathrm{N}$ lebih merasakan kebebasan apabila sedang berada di lingkungan KDS, yang mana mereka lebih terbuka dan teman-teman yang lain sudah mengerti status mereka. Lingkungan KDS pun menerima apapun keadaan dan latar belakang dari setiap ODHA termasuk juga ibu rumah tangga. Namun informan L merasa biasa saja tidak ada perbedaan kebebasan hidup dari sebelum dan sesudah terinfeksi HIV/AIDS.

f. Cara menyikapi kebebasan hidup dengan tetap berpegang teguh pada keimanan, melakukan aktivitas seperti biasa, tetap menjaga kesehatan, dan membuktikan 
bahwa ODHA sama seperti orang lain yang dapat hidup normal seperti biasa.

\section{Sikap terhadap Kematian}

Kematian dapat terjadi kepada siapa saja. Kematian bagi setiap orang memiliki makna yang berbeda-beda. Orang-orang yang menderita sakit parah pun akan menyikapi kematian dengan hal-hal yang berbeda-beda. Seperti ibu rumah tangga yang terinfeksi HIV/AIDS juga memiliki sikap yang berbeda dalam menghadapi kematian.

a. Pandangan terhadap kematian bagi ibu rumah tangga dengan HIV/AIDS di KDS "Smile Plus" Temanggung, keempat informan mengatakan bahwa kematian pasti akan dialami oleh setiap orang, ditambah dengan penuturan informan $\mathrm{P}$ yaitu kematian dapat datang secara tibatiba sehingga dalam hidup ini harus digunakan sebaik-baiknya, tetap menjaga kesehatan dengan meminum ARV secara rutin.

b. Cara menyikapi kematian dengan lebih mendekatkan diri kepada Tuhan, melakukan banyak kebaikan, pengobatan rutin dan menjaga kesehatan.

\section{Pikiran tentang Bunuh Diri}

Terkadang pikiran untuk bunuh diri terlintas di benak seorang ODHA tak terkecuali ibu rumah tangga yang terinfeksi HIV/AIDS di KDS "Smile Plus" Temanggung. Dua dari empat informan mengatakan bahwa tidak pernah berpikir untuk melakukan bunuh diri, sedangkan dua lainnya mengatakan pernah berpikir untuk bunuh diri.

a. Pikiran untuk bunuh diri bagi ibu rumah tangga dengan HIV/AIDS di KDS "Smile Plus" Temanggung dikarenakan beberapa faktor. Menurut informan $\mathrm{P}$ dan $\mathrm{N}$ salah satu faktornya adalah tidak memiliki harapan hidup dan mereka sebenarnya adalah korban dari suami mereka. Namun informan $\mathrm{L}$ dan informan $\mathrm{F}$ tidak perah berpikiran untuk bunuh diri karena mereka masih memiliki tanggung jawab dan ingin membahagiakan orang-orang terdekat.

b. Waktu berpikir untuk bunuh diri informan $\mathrm{P}$ adalah beberapa saat setelah mengetahui terinfeksi HIV yaitu sekitar satu minggu dan informan $\mathrm{N}$ tiga bulan setelah mengetahui positif HIV/AIDS.

c. Alasan berpikir bunuh diri karena tidak ada lagi harapan untuk hidup dan berumah tangga serta sudah merasa down atau putus asa dalam menghadapi kenyataan hidupnya.

d. Upaya mencegah bunuh diri adalah secara spiritual yaitu mendekatkan diri kepada Allah, dan dengan melihat orang tua sebagai motivasi untuk terus sehat, motivasi lain juga diberikan oleh KDS "Smile Plus" untuk membantu mencegah terjadinya tindakan bunuh diri.

\section{Kepantasan untuk Hidup}

Kepantasan untuk hidup disini bagi ibu rumah tangga dengan HIV/AIDS di KDS "Smile Plus" Temanggung adalah dapat dilihat dari pentingnya perjuangan hidup dan cara memperjuangkan hidup. Sehingga,

mereka merasa sudah lebih mengerti dan memahami bagaimana menjalani hidup lebih baik lagi walaupun dengan status ODHA (Orang dengan HIV/AIDS).

a. Pentingnya memperjuangkan hidup bagi ibu rumah tangga dengan HIV/AIDS di KDS "Smile Plus" Temanggung adalah karena hidup ini penuh dengan cobaan dan pengorbanan, sehingga kita bisa memperjuangkan hidup contohnya dengan membantu orang tua dan juga berusaha 
semaksimal mungkin serta ikhlas menerima semuanya.

b. Cara memperjuangkan hidup ibu rumah tangga dengan HIV/AIDS berbeda. Menurut informan $\mathrm{P}$ yaitu berusaha dan bekerja semampunya. Informan $\mathrm{N}$ mengatakan menjadi pribadi yang lebih baik lagi, selalu ikhlas dan ikhtiar menerima cobaan hidup, bahagia, bersyukur, bersikap jujur. Cara memperjuangkan hidup informan $\mathrm{F}$ dan informan $\mathrm{L}$ adalah melakukan hal-hal yang positif, bahagia, dan menjaga kesehatan.

\section{PEMBAHASAN}

Setiap manusia mengalami hambatan dan cobaan pada hidupnya masing-masing. Hambatan dan cobaan hidup setiap orang berbeda-beda ada yang dengan diberikan musibah berupa sakit seperti ibu rumah tangga dengan HIV/AIDS di KDS "Smile Plus" Temanggung ini. Kemudian, mereka akan memiliki tujuan hidup yang akan mereka penuhi atau mereka capai sehingga hidupnya akan terasa bermakna dan tidak merasakan hampa. Hal tersebut sesuai dengan pengertian kebermaknaan hidup menurut Bastaman (2007) bahwa kebermaknaan hidup merupakan keadaan

penghayatan hidup yang penuh makna yang membuat individu merasakan hidupnya lebih bahagia, lebih berharga, dan memiliki tujuan yang mulia untuk dipenuhinya. Individu yang mencapai kebermaknaan hidup akan merasakan merasakan hidupnya penuh makna, berharga, dan memiliki tujuan, sehingga individu terbebas dari perasaan hampa dan kosong.

\section{Karakeristik Ibu Rumah Tangga dengan HIV/AIDS}

Dari keempat informan ibu rumah tangga dengan HIV/AIDS mengatakan bahwa faktor penyebab terinfeksi HIV adalah melalui hubungan seksual dengan suami mereka. Hal ini sesuai dengan penjelasan cara penularan HIV/AIDS menurut UNAIDS (2004) yaitu salah satunya melalui hubungan seksual. Hubungan seksual yang tidak terlindung atau tidak menggunakan pengaman dengan orang yang sudah terinfeksi HIV dan AIDS. Hubungan seksual ini bisa homoseksual (sesama jenis) ataupun heteroseksual (berlainan jenis). Virus dapat masuk ke tubuh melalui lapisan/selaput vagina, vulva, penis, rektum atau mulut. Perempuan lebih rawan tertular HIV dibanding laki-laki. Diantara perempuan, risiko terbesar ialah gadis remaja dan perempuan muda karena sistem reproduksinya yang tengah berkembang membuat mereka lebih mudah terkena infeksi jika tidak ada pelindung terhadap infeksi menular seksual (IMS), termasuk HIV.

Dua informan mengatakan bahwa mereka memiliki anak namun sudah meninggal dunia saat bayi karena tertular HIV/AIDS melalui air susu ibu dan saat proses kelahiran. Hal ini terjadi karena informan belum mengetahui bahwa ia terinfeksi HIV/AIDS sehingga tidak dapat berupaya untuk mencegah penularan virus kepada bayinya. Hal ini sesuai dengan penjelasan mengenai cara penularan HIV/AIDS melalui ibuhamil kepada bayinya menurut UNAIDS (2004) yaitu Penularan dapat terjadi selama kehamilan, persalinan, atau menyusui. Air susu ibu dari ibu yang terinfeksi HIV juga mengandung virus itu. Jadi, jika bayi disusui oleh ibu HIV-positif, maka bayi tersebut bisa tertular. Selain itu, terdapat satu informan yang mengatakan bahwa anaknya tidak tertular HIV dikarenakan sudah mengikuti program hamil sesuai prosedur untuk mencegah anaknya tertular HIV sejak dalam kandungan.

Proses mencapai kebermaknaan hidup menurut Bastaman (2007) adalah tahap derita 
(peristiwa tragis, penghayatan tanpa makna). Dalam tahap ini, individu berada dalam keadaan yang tidak bermakna. Bisa jadi mengalami peristiwa tragis yang tidak menyenangkan. Begitu pula dengan reaksi pertama kali yang ditunjukkan keempat ibu rumah tangga dengan HIV/AIDS saat mengetahui positif HIV adalah syok, down, tidak memiliki harapan hidup, takut karena minimnya pengetahuan tentang HIV/AIDS. Hal ini sesuai dengan pernyataan terkait ciri-ciri kehilangan makna hidup menurut Crumbaugh dan Maholick (dalam Bastaman, 2007) adalah perasaan hampa, gelisah, merasa tidak memiliki tujuan hidup, merasa hidup tidak berarti, serba salah, kehilangan minat, dan kehilangan inisiatif sehingga individu tidak ada gairah lagi untuk menjalani kehidupan di masyarakat.

Disamping itu, hasil penelitian menunjukkan mereka tidak menolak dan tetap menerima keadaannya yang positif HIV walaupun dengan waktu yang tidak singkat. Mereka berpikir hal ini sudah terjadi, dan tetap harus menjalani hidup untuk dan masih memiliki masa depan. Hal ini sesuai dengan proses mencapai kebermaknaan hidup pada tahap penerimaan diri menurut Bastaman (2007) yaitu tahap penerimaan diri (pemahaman diri dan pengubahan sikap) individu mulai sadar dan menerima serta memahami keadaannya dari kisah tragis yang dialaminya sehingga mau tidak mau harus membuat pengubahan sikap yang lebih baik.

\section{Tujuan Hidup Ibu Rumah Tangga dengan HIV/AIDS}

Tujuan hidup menurut Bastaman (2007) yaitu cita-cita yang terukur disebut tujuan atau goal yang memberi arah pada semua kegiatan. Dari hasil penelitian yang dilakukan, peneliti menganalisis bahwa hal-hal yang dijadikan tujuan hidup ibu rumah tangga dengan
HIV/AIDS adalah selalu diberikan kesehatan. Kesehatan ibu rumah tangga dengan HIV/AIDS sangat berharga karena dengan tubuhnya yang sehat mereka memiliki modal untuk melakukan segala macam aktivitas di lingkungan sekitarnya.

Hasil penelitian menunjukkan berbagai macam tujuan hidup bagi ibu rumah tangga dengan HIV/AIDS di KDS "Smile Plus" Temanggung, mereka telah mencapai tahap penemuan makna hidup dengan menentukan tujuan hidup mereka masing-masing. Hal ini sesuai dengan penjelasan mengenai tahap kedua dalam proses mencapai kebermaknaan hidup menurut Bastaman (2007) yaitu tahap penemuan makna hidup (penemuan makna dan penentuan tujuan hidup). Individu mulai menyadari akan hal-hal penting dalam kehidupannya yang kemudian ditetapkan sebagai tujuan hidupnya. Hal ini bersumber dari nilai kreatif, nilai penghayatan dan nilai sikap.

Melihat dari pernyataan tujuan hidup yang berbeda-beda dari ibu rumah tangga dengan HIV/AIDS di KDS “Smile Plus" Temanggung, hal ini sesuai dengan pernyataan Bastaman (2007) bahwa karakteristik kebermaknaan hidup bersifat unik, pribadi dan temporer. Apa yang dianggap berarti oleh seseorang belum tentu berarti pula bagi pula bagi orang lain. Dalam hal ini makna hidup seseorang dan apa yang bermakna bagi dirinya biasanya sifatnya khusus, berbeda dan tak sama dengan makna hidup orang lain, serta mungkin pula dari waktu ke waktu berubah.

\section{Kepuasan Hidup}

Kepuasan hidup menurut Crumbaugh dan Maholick (Koeswara, 1992) yaitu penilaian seseorang terhadap hidupnya, sejauh mana ia bisa menikmati dan merasakan kepuasan dalam hidup dan aktivitas-aktivitas yang dijalaninya. Sesuai dengan hasil penelitian yang dilakukan di lapangan, peneliti menemukan bahwa ibu rumah 
tangga dengan HIV/AIDS merasakan kepuasan hidup dengan melakukan hal-hal yang bermanfaat bagi orang lain serta selalu bersyukur atas apa yang dimiliki saat ini.

Tahap terakhir proses mencapai hidup bermakna menurut Bastaman (2007) adalah tahap kehidupan bermakna (penghayatan bermakna, kebahagiaan). Pada tahap ini timbul perubahan kondisi hidup yang lebih baik dan telah mencapai tujuan hidupnya dengan kebahagiaan sebagai hasilnya. Begitu pula dengan hasil temuan di lapangan oleh peneliti, salah satu contoh bermanfaat bagi orang lain adalah dengan membantu memotivasi sesama ODHA khususnya untuk anggota baru. Hal ini dilakukan karena ternyata walaupun dengan keadaan mereka yang berstatus ODHA masih bisa bermanfaat bagi orang lain. Selain itu, salah satu kepuasan hidup bagi ibu rumah tangga dengan HIV/AIDS adalah bersyukur kepada Tuhan atas apa yang dinikmati sekarang Hal ini sesuai dengan penjelasan sumber-sumber kebermaknaan hidup dari Frankl dalam Bastaman (2007) yaitu creative values (nilainilai kreatif) mencakup kegiatan bekerja, berkarya serta melaksanakan tugas dan kewajiban sebaik-baiknya dengan penuh tanggung jawab. Menekuni suatu pekerjaan dan meningkatkan keterlibatan pribadi terhadap tugas serta berusaha untuk bekerja sebaikbaiknya merupakan salah satu contoh kegiatan berkarya. Melalui berkarya dan kerja kita dapat menemukan arti hidup dan menghayati kehidupan secara bermakna.

\section{Kebebasan Hidup}

Kebebasan hidup yang dirasakan sebelum dan sesudah terinfeksi HIV ibu rumah tangga dengan HIV/AIDS adalah sebelum terinfeksi HIV merasa lebih bebas berosialisasi dan melakukan segala kegiatan. Namun setelah terinfeksi HIV menjadi lebih sensitif dan kurang percaya diri, muncul rasa khawatir apabila orangorang disekitarnya mengetahui statusnya sebagai ODHA. Saat ada pertemuan di masyarakat merasa seperti terdiskriminasi oleh orang-orang sekitarnya. Perasaan-perasaan tersebut yang mengganggu kondisi psikososial ibu rumah tangga dengan HIV/AIDS. Hal ini sesuai dengan pernyataan Safarino (1998) dalam Kusumawijaya, suatu penyakit dan akibat yang diderita, baik akibat penyakit ataupun intervensi medis tertentu dapat menimbulkan perasaan negatif seperti kecemasan, depresi, marah, ataupun rasa tidak berdaya dan memperbesar kecenderungan seseorang terhadap suatu penyakit tertentu.

Kemudian cara menyikapi kebebasan yang dilakukan ibu rumah tangga dengan HIV/AIDS di KDS "Smile Plus" Temanggung adalah dengan selalu berpegang teguh dalam keimanan. Percaya bahwa Tuhan yang memberikan kebebasan hidup. Mempercayai bahwa segala sesuatu yang terjadi sudah diatur oleh Tuhan. Sehingga sebagai manusia tetap harus selalu melakukan hal-hal kebaikan seperti memberikan motivasi hidup bagi ODHA yang lain agar tetap semangat menjalani hidup. Hal tersebut sesuai dengan penjelasan Frankl dalam Bastaman (2007) yang menyebutkan bahwa Keyakinan dan penghayatan akan nilai-nilai kebenaran, kebajikan, keindahan, keimanan, dan keagamaan serta cinta kasih. Menghayati dan meyakini suatu nilai dapat menjadikan seseorang berarti hidupnya. Beberapa orang merasa menemukan arti hidup dari agama yang diyakininya, menekuni cabang seni tertentu, maupun dengan mencintai dan dicintai seseorang akan merasakan hidupnya penuh dengan pengalaman hidup yang membahagiakan.

\section{Sikap terhadap Kematian}

Crumbaugh dan Maholick (Koeswara, 1992) menjelaskan Sikap terhadap kematian, 
yaitu bagaimana seseorang berpandangan dan kesiapannya dalam menghadapi kematian. Orang yang memiliki makna hidup akan membekali diri dengan berbuat kebaikan, sehingga dalam memandang kematian akan merasa siap untuk menghadapinya. Demikian hal nya dengan ibu rumah tangga dengan HIV/AIDS yang memandang kematian adalah hal yang pasti dialami oleh setiap orang. Kematian juga terkadang datang secara tiba-tiba sehingga ibu rumah tangga dengan HIV/AIDS menyikapi hal tersebut dengan lebih mendekatkan diri kepada Allah. Memperbaiki hubungan dengan Allah, dengan memaksimalkan kewajiban-kewajiban seperti beribadah. Selain itu diimbangi dengan terus melakukan banyak kebaikan sesama manusia.

\section{Pikiran tentang Bunuh Diri}

Hawari (2004) dalam Kusumawijaya mengatakan bahwa penderita AIDS akan mengalami krisis kejiwaan pada dirinya, pada keluarganya, pada orang yang dicintainya dan pada masyarakat. Krisis kejiwaan tersebut adalah dalam bentuk kepanikan, ketakutan, kecemasan, ketidakpastian, keputusasaan, dan stigma. Perlakuan terhadap penderita AIDS seringkali bersifat diskriminatif dan risiko bunuh diri pada penderita AIDS cukup tinggi akibat depresi mental yang dialaminya. Demikian halnya dengan pikiran-pikiran tentang bunuh diri dialami oleh beberapa ibu rumah tangga dengan HIV/AIDS, terutama saat dirinya divonis terinfeksi HIV/AIDS. Pikiran tentang bunuh diri muncul beberapa saat setelah dirinya terinfeksi HIV Hal ini tentunya membuat depresi, syok, dan kehilangan harapan hidupnya, takut terdiskriminasi oleh lingkungan sekitar.

Ibu rumah tangga dengan HIV/AIDS lainnya tidak pernah berpikir untuk bunuh diri, karena dirinya merasa bahwa masih memiliki tanggung jawab, harapan dan cita-cita yang harus diwujudkan. Hal tersebut sesuai dengan penjelasan dari Crumbaugh dan Maholick (dalam Koeswara, 1992) yaitu Pikiran tentang bunuh diri, yaitu bagaimana pemikiran seseorang tentang masalah bunuh diri. Bagi orang yang mempunyai makna hidup akan berusaha menghindari keinginan untuk melakukan bunuh diri atau bahkan tidak pernah memikirkannya.

\section{Kepantasan untuk Hidup}

Crumbaugh dan Maholick (Koeswara, 1992) Kepantasan hidup, adalah evaluasi seseorang tentang hidupnya apakah ia merasa bahwa sesuatu yang dialaminya merupakan sesuatu yang wajar sekaligus menjadi tolok ukur baginya tentang mengapa hidup itu layak untuk diperjuangkan. Demikian hal nya dengan hasil penelitian yang dilakukan oleh peneliti terhadap ibu rumah tangga dengan HIV/AIDS di KDS "Smile Plus" Temanggung, yang mana menurut mereka hidup itu penuh dengan pengorbanan dan banyak cobaan sehingga perlu untuk diperjuangkan. Cara-cara memperjuangkan hidup dengan menjaga kesehatan, menjadi pribadi yang lebih baik, senantiasa bersyukur

atas apa yang dimiliki, serta sabar dan ikhlas dalam menerima cobaan hidup.

Berdasarkan Analisis hasil penelitian diatas, ditemukan masalah yaitu:

1. Permasalahan dalam mencapai tujuan hidup, yaitu tidak semua orang mau menerima keadaan ibu rumah tangga dengan statusnya sebagai ODHA. Disamping itu, dari pasangan juga masih ada yang takut memiliki keturunan dari dirinya, sehingga itu tujuan hidup memiliki keturunan.

2. Permasalahan mengenai kebebasan hidup di lingkungan sekitar, dimana beberapa masyarakat dan keluarga masih memberikan stigma negatif dan melakukan diskriminasi. Hal tersebut membuat ibu rumah tangga 
dengan HIV/AIDS tidak percaya diri apabila berada di lingkungan sekitarnya.

Mengacu Berdasarkan hasil analisis masalah diatas, upaya yang dapat dilakukan yaitu

1. Memberikan edukasi terhadap ODHA dan OHIDHA maupun masyarakat terkait hal-hal mengenai HIV/AIDS khususnya cara penularan HIV/AIDS, pencegahan HIV/AIDS dan cara merawat ODHA.

2. Memberikan pelatihan keterampilan terhadap ODHA, OHIDHA, dan mayarakat dalam perawatan ODHA.

3. Memberikan motivasi dan penguatan kepada ODHA terkait kondisi psikologis dan kondisi sosial dalam bermasyarakat.

Keberadaan sistem sumber sangat dibutuhkan untuk memecahkan permasalahan yang ada. Sistem sumber formal dapat dilakukan dengan tergabung dalam Kelompok Dukungan Sebaya "Smile Plus" Temanggung, Caritas Germany, Yayasan Lenterha Surakarta, Gaya Mahardika Surakarta. Dan MItra Alam Surakarta.

Sistem sumber informal yaitu keluarga sebagai penguatan psikis melalui pemberian motivasi dengan rasa cinta dan kasih sayang dengan tidak memberi stigma dan perlakuan berbeda terhadap ibu rumah tangga dengan HIV/AIDS dengan anggota keluarga lain. Teman sebaya juga dapat membantu untuk menguatkan sesama ODHA yang memiliki keadaan dan kondisi yang sama. Serta pengurus KDS "Smile Plus" Temanggung yang dapat membantu dalam mendampingi dan memberikan arahan kepada ibu rumah tangga dengan HIV/AIDS.

Sistem sumber kemasyarakatan dapat dimanfaatkan untuk memperoleh edukasi dan motivasi kepada ODHA, OHIDHA, dan masyarakat seputar HIV/AIDS; mengecek secara berkala perkembangan kesehatan ODHA, dan mendapatkan bantuan nutrisi atau pemberdayaan ODHA. Sistem sumber ini meliputi Dinas Kesehatan, Dinas Sosial, Puskesmas, RSUD, dan Komisi Penanggulangan AIDS Kabupaten Temanggung; serta Balai Rehabiltasi sosial AMPK “Antasena" Magelang dan Loka Rehabilitasi Sosial Orang Dengan HIV "Kahuripan" Sukabumi.

\section{KESIMPULAN}

Ibu rumah tangga dengan HIV/AIDS terinfeksi dari pasangannya. Mereka memiliki masalah yang kompleks dengan pasangannya, anaknya, keluarganya, bahkan dengan masyarakat di sekitarnya. Kondisi ini sangat berdampak pada kebermaknaan hidupnya seperti harapan hidup hilang, merasa hidup tidak berarti dan tidak percaya diri dalam lingkungan masyarakat.

Berdasarkan hasil penelitian, ibu rumah tangga dengan HIV/AIDS telah mencapai kebermaknaan hidup dari aspek tujuan hidup, kepuasan hidup, kebebasan hidup, sikap terhadap kematian, pikiran tentang bunuh diri, dan kepantasan untuk hidup. Mereka telah mencapai kebermaknaan hidupnya dan telah melewati berbagai tahap dalam mencapai kebermaknaan hidup. Sekarang mereka memiliki tujuan hidup yang jelas, dan terarah serta merasakan dirinya lebih berharga, bermanfaat dan bahagia walaupun dengan statusnya sebagai ODHA. Pada kenyataannya, mereka tetap memiliki beberapa hambatan dalam mencapai tujuan hidupnya.

Peningkatan Kapasitas Kehidupan Ibu Rumah Tangga dengan HIV/AIDS di Kelompok Dukungan Sebaya "Smile Plus" Temanggung perlu dilakukan untuk meningkatkan kemampuan kehidupan ibu rumah tangga dengan HIV/AIDS di Kelompok Dukungan Sebaya 
"Smile Plus" Temanggung. Para ibu rumah tangga dengan HIV/AIDS dapat meningkat pengetahuannya sehingga akan menumbuhkan kembali semangat, dukungan, penguatan psikologis dan sosial untuk mencapai kebermaknaan hidup secara penuh didalam keluarga dan lingkungan masyarakat sekitarnya.

\section{DAFTAR PUSTAKA}

Agustinova, Danu Eko. 2015. Memahami Metode Penelitian Kualitatif: Teori dan Praktik. Yogyakarta:Calpulis

Astuti, A. \& Budiyanti, K. (2010). Hubungan antara dukungan sosial yang diterima dengan kebermaknaan hidup pada odha (orang dengan HIV/AIDS). Emphaty

Ayash-Abdo, H. 2002. Adolescent Suicide: an Ecological Approach. Wiley InterScience. 34(4). 459-475.

Bastaman, H.D. 2007. Logoterapi: Psikologi untuk Menentukan Makna Hidup dan Meraih Hidup Bermakna. Jakarta:PT.Raja Grafindo Persada

Dinas Kesehatan Kabupaten Temanggung. 2018. Profil Kesehatan Kabupaten Temanggung Tahun 2018. Temanggung

Direktorat P2P Kemenkes RI. 2020. Laporan Perkembangan HIV AIDS \& Penyakit Menular Seksual (PIMS) Triwulan IV Tahun 2020. Jakarta: Kementerian Kesehatan RI

Frankl, V. E. 2000. Man's Search for Ultimate Meaning. New York: Basic Books

Frankl, V. E. 2003. Logoterapi : Terapi Psikologi Melalui Pemaknaan Eksistensi. Yogyakarta: Kreasi Wacana

Garvin Terjemah Koswara, Herry, dkk. 2013. Group Work. Bandung:STKS Bandung

Katiandagho, Desmon. 2017. Epidemiologi HIVAIDS. Bogor: In Media

Kementerian Negara Pemberdayaan Perempuan Republik Indonesia. Pemberdayaan Perempuan dalam Pencegahan Penyebaran HIV-AIDS. Jakarta

Koeswara, E. 1992. Logoterapi: Psikoterapi Viktor Frankl. Yogyakarta: Kanisius

Kusumawijaya, Paputungan. 2012. Dinamika Psikologis Pada Orang dengan HIV dan
AIDS. Jurnal Psikologi. Universitas Ahmad Dahlan

Moleong, Lexy J. 2004. Metodologi Penelitian Kualitatif. Bandung : PT.Remaja Rosdakarya Sidiq, Umar., Choiri, Moh.Miftachul. 2019. Metode Penelitian Kualitatif di Bidang Pendidikan. Ponorogo: CV. Nata Karya

Sugiyono. 2012. Memahami Penelitian Kualitatif. Bandung: Alfabeta

Sugiyono. 2016. Metode Penelitian Kuantitatif, Kualitatif, dan $R \& D$. Bandung: Alfabeta

Sukardi. 2010. Metodologi Penelitian Pendidikan. Jakarta : PT. Bumi Aksara

Susilowati, E., \& Dewi, K. (2019). Living Experience Of Women With Hiv/Aids In West Java INDONESIA. Indonesian Journal of Social Work, 3(1).

UNAIDS. 2004. Hidup Bersama HIV dan AIDS: Informasi Bagi Karyawan di Semua Badan PBB beserta Keluarganya. Jakarta

Yayasan Spiritia. 2016. Hidup dengan HIV/AIDS. Jakarta: Yayasan Spiritia

Yayasan Spiritia. Lembaran Informasi tentang HIV/AIDS untuk Orang yang Hidup dengan HIV/AIDS (ODHA). Jakarta: Yayasan Spiritia

\section{Internet}

Badan Pusat Statistik Provinsi Jawa Tengah. (2018). Jumlah Kasus HIV/AIDS, IMS, DBD, Diare, TB, dan Malaria Menurut Kabupaten/Kota di Provinsi Jawa Tengah, 2017-2018. Retrieved August 3, 2020, https://jateng.bps.go.id/dynamictable/2019/02/ 19/400/jumlah-kasus-hiv-aids-ims-dbd-diaretb-dan-malaria-menurut-kabupaten-kota-diprovinsi-jawa-tengah-2017.html

Badan Kependudukan dan Keluarga Berencana Nasional. (2019). Kasus HIV/AIDS dikalangan Ibu Rumah Tangga Meningkat. Retrieved August 18, 2020, https://www.bkkbn.go.id/detailpost/kasus-hivaids-dikalangan-ibu-rumah-tangga-meningkat Saputra, Imam Yuda. (2018). Penderita HIV/AIDS di Semarang Terbanyak seJateng. Retrieved August 4, 2020, https://www.solopos.com/penderitahivaids-di-semarang-terbanyak-sejateng-956036 
Widiyanto, Danar. (2019). Penderita HIV/AIDS di Kabupaten Temanggung Mencapai 480 Kasus. Retrieved August 3, 2020, https://www.krjogja.com/beritalokal/jateng/kedu/penderita-hivaids-di-kabupaten-temanggungmencapai-480-kasus/ 